\title{
Inculcating the Value of Character Education through Malay Tales at Early Childhood in Kindergarten Institution
}

\author{
Ratih Baiduri \\ Department of Anthropology Education \\ The Faculty of Social Sciences Universitas Negeri Medan \\ Medan, Indonesia \\ e-mail: ratihbaiduri215@gmail.com
}

\author{
Leylia Khairani \\ Department of Hospitality \\ Sahid Institute of Tourism \\ Jakarta, Indonesia \\ e-mail: liakhairani@yahoo.com
}

\begin{abstract}
Fairy tale is one of the local wisdom of society that can be used as media of character education values of character in children since early age. Important character education is instilled from an early age because in this, golden period is the most effective time in providing knowledge and understanding as well as the inculcation of character education. The purpose of this study is to examine the values of character education in fairy tales that can be embedded in early childhood in kindergarten education institutions. This research uses a qualitative method. Data collection techniques in this study are literature studies and in-depth interviews with Malay cultural figures. From the research, results obtained data that the tale of Malay titled Princess at Pucuk Kelumpang has character education values that include leadership and responsibility, patience, loyalty, and honesty. The values of character education are derived from local cultural knowledge and values that are delivered orally through storytelling. Thus, in addition to gaining knowledge and understanding of the virtues that come from the local culture, children can also recognize and preserve their culture.
\end{abstract}

Keywords-Malay Tale, Character Education, Kindergarten

\section{INTRODUCTION}

In the last few decades, there has been a phenomenon of changing the orientation of both parents and school to education, including education as early childhood in Kindergarten Institution. Parents are increasingly motivated and feel more proud to make their children have the ability to think academically (hard skill) than well behaved, disciplined, polite and responsible (soft skill). Educational institutions (schools), too, tend to engrain by responding to a number of codifications of forms and models of education. This mechanistic education orientation has of course robbed the child's natural development.

In general, parents have an obsession and pride in the achievements of children who put forward aspects of cognitive (hard skill) among others, the ability to read and count as children of elementary school. This will "rob" children's chances of playing while learning about life between selfreliant in the self-organization such as queuing up, putting things in the right place after playing, throwing garbage properly, loving the environment, and respecting friends and listening to teachers and people's advice old. The pride of these achievements resulted in the children being "prosecuted" having the ability to put forward the intellectual intelligence to ignore the moral values. The mechanistic learning system results in the learners not getting an understanding of learning the values of togetherness, harmony, compassion, which can lead to children becoming rebels, dissidents and other asocial behaviors.

Asocial phenomena occur among children, and adolescents can be explained through the view of Hurlock [1] which states juvenile delinquency is not a new phenomenon of adolescence but a continuation of the pattern of association behavior began in childhood. According to Hurlock since the age of 2-3 years, there is a possibility, we can recognize the child who later became a juvenile delinquent.

Manifestation of attitudes and behavior of adolescents through negative behavior shows that there has been a moral crisis among students. Lickona [2] posited a moral crisis that occurred in the United States due to the lack of solid character education of learners. Some forms of moral crisis are: (1) Violence and anarchy; (2) Theft; (3) Fraudulent acts; (4) Abandonment of applicable rules; (5) Student strikes; (6) Intolerance; (7) The use of bad language; (8) too early sexual maturity and perversion and (9) self-destructive attitude. What is happening in America does not close the possibility has happened also in Indonesia with the indicators mentioned by Lickona.

Through various phenomena that reflect the indicator of moral crisis as mentioned Lickona, it is necessary recognition and socialization as well as the inculcation of the values of character education that is fun in children. The noble character planting associated with character formation that contains ethics in children is not only limited to understanding, but needs to be implemented in everyday life. Good ethical planting will shape the characters, attitudes, and behaviors that strengthen soft skills in instilling excellent habits. The 
cultivation of character to form the characters through fun activities can be done through storytelling activities. Activity of character education values through storytelling can be done by revitalizing local wisdom that is by digging local folklore. Folklore is chosen as a medium in instilling ethical learning because it contains noble values that can be used as a guide for the life of his generation, such as: values of honesty, responsibility, cooperation, discipline, religion and so forth. The moral virtues and attitudes toward a person related to ethics can put humanity's major emphasis on behavior.

Tales can stimulate the growth of the soul. Noble values in fairy tales can be used as a means of educational support to form an exemplary personality. The leading figures of children in folklore will be role models in their attitude of life [3]. As revealed by Sayy [4] that the soul to the child can be built through noble character in fairy tales. The tale which is one part of the oral folklore and one that falls under the category of folklore is very close to the world of early childhood so it will be effective in stimulating the psychic who can build the character and ethics in the child.

\section{TALES AS MEdiA FOR CHARACTER EdUCATION}

The idea of character education in Indonesia can be traced from the folklore form of society. There are several types of oral folklore, one of which is a fairy tale. Fairy tale as a folklore of a particular culture is a form of cultural expression that represents the life to its people. Good values that can be absorbed and internalized during the story-telling process will be more easily understood because socioculturally are closer to the speaker and the listener.

Fairy tale is a representative media in providing understanding of the virtues and character education. The tale is one of the forms of oral folklore, which includes the folk prose story. Folklore is a part of society culture bound in a certain collectivity and passed down from generation to generation members to the society orally. Fairy tale is a story of people's prose that is considered not really happening, is told primarily for entertainment, although many also portray the truth, containing the lesson (moral), or even satire [5]. Today, children are rarely never heard a fairy tale spoken as an oral tradition within the family. In addition, our community literacy tradition is also minimal so that knowledge about books on the theme of folklore is not an interest for children. Storytelling has been replaced by watching television and playing games on hand phones or playstations.

From an early age, children are actually good listeners. Children aged 4-5 years have been able to receive and feel the beauty of the essence of the story because the intelligence of his brain surpassed his body power [6]. At the age of less than four years, they have been capable of capture the narrated story, although they have not been able to distinguish the imagination and the reality. Folklore can be conveyed by storytelling during free time or included in the literary learning in school. Submission of fairy tales should focus on the moral values that exist in the folklore through the characters. Attitudes and behaviors of figures that exist in the folklore can exemplify ethics and morale. The ethics and morals of the characters within the story are reflected in the attitude of responsibility, discipline, cooperation, caring, honesty, cooperation, hard work, etc. [7].

Psychologically, children are quite easy to accept folklore. Children are easier to memorize and imagine through stories, songs, and games. In folklore [5] be it myths, legends, and fairy tales of children can learn the values of character education while playing in a pleasant atmosphere. In this way, the accepted learning activity is embedded within him. So during this period of development in these golden period children can improve their cognitive-logical abilities.

Through folklore in the form of oral folklore, the process of learning character education in early childhood can be applied. Folklore has a philosophy and character that can be imitated by young children. With the technique of telling folklore, the figures of the story can be heard and accepted by the children. Rolina [8] reveals several methods that can be used such as picture book media with attractive colors, hand puppets, character costumes, finger puppets, or role playing techniques. With learning media, the content of moral messages in the story can be taken by children. The use of folklore in the application of character education in children is appropriate because the folklore is very close socially and culturally with the society. In addition, through folklore children are introduced to the values of indigenous characters of local communities.

\section{MALAY FOLKLORE PRINCESS PUCUK KELUMPANG}

The values of character education to be conveyed and implanted to early childhood are derived from the Malay fairy tale entitled Princess Pucuk Kelumpang [9]. Here below will be told the full story of the fairy tale.

In the past, there was a country called Negeri Kelumpang. Kelumpang became its name because there are so many Kelumpang trees towering over the vast forests throughout the country. The country of Kelumpang is governed by a just and authoritative King. The King and his queen were loved and exalted by the inmates of the palace, especially by the people. Behind the King's courage and might, there is one thing that always hinders him. After a dozen years of marrying his wife (called Empress) beloved, the King has not been yet gifted with a descendant. This makes the King unhappy and thinks of his fate. In the heart of the King he thought, what will happen in this country if he has no offspring as the heir for the throne. In the midst of such anxiety, the king asked a counselor (called the Wazir) to accompany him for entertainment, and the king decided to hunt.

The forests of the country Kelumpang has a wealth of animals, so the King decided to hunt there. The provisions for hunting were prepared, then the King asked for permission and conveyed his intentions to the Empress, and was approved by the Empress. The King, Wazir, Commander and some of the palace guard finally set out to start their hunt. In the midst of his hunt, the King was slightly disappointed that all day he only managed to get a small mouse deer. Feeling exhausted, the King decided to rest. The king fell asleep under a tall Kelumpang tree, while the guards carefully look after the King, so that the King is free from a wild animal.

The king fell asleep. The sleep is then filled by strange dreams. In the dream, the King meets an old white man; hair, mustache, long beard to touch the colorless chest. The old man 
said that the King would have a descendant to be born consort. Before long, the King woke up. In his confusion, the King asked the Wazir for advice. Wazir says that if the dream occurs during the day, then the dream will come true.

But then there was a concern in the King's heart. Realizing the concern, Wazir asked, "Forgive my master's servant! What is it that makes you worried? " The king then explains that he is grateful if he finally gets offspring. However, he is worried if his offspring is a daughter, not a son. The king feels if his offspring is a princess, then the princess cannot bequeath her throne. There was never a country ruled by a woman at that time.

However, the King's concern gradually disappeared until the King got the good news that the Queen was pregnant. Three months is the age of the Queen's content. Suddenly, the King decided to go sailing to the other countries. The purpose is to visit and exchange the crops of the State of Kelumpang with the products from other countries. In his plan, he thought of a descendant, again haunted the King's mind.

Actually, there have been many invitations from foreign countries to the King to establish cooperative relations. Without the trip and the journey of the King to overseas lands has reached a dozen years. So also with the Princess who is now teenagers. She grew up to be a beautiful and elegant young woman. One day, the king went home. His return was greeted by all the inhabitants in the country.

Arriving at the palace, after resting, the King immediately asked the Queen about his descendants. The Queen with a sad face said that the baby who was born is a princess and following the orders of the King, the baby has been kept away from the palace and unknown to its existence. "Good," said the King. "You have done my word." However, then unexpectedly came a blind crow who said to the King that the Princess was actually hidden and nurtured and well cared for in a place protected on the tree Kelumpang. The wrath of the King was instantaneous. "That's right?" He snarled at the Queen. Queen cannot answer. She cry with body vibrate. The king demands the Queen to say where the Princess is really hidden. Unable to dodge, the Queen finally says and shows where the Princess has been hiding.

However, as long as the Queen has not given offspring, the King feels worried if he has to leave his wife for a long period of time. So, when the Consort had been three months pregnant, the King decided to make the voyage in the framework of a state visit. The king is convinced that all the ladies and other court dwellers will keep the Queen and her baby candidate well and lovingly. So, after receiving the blessing of the Consort, the King prepares for his voyage.

Before leaving, the King gave his wife the will, "O my Consort, I will go to sail for the prosperity of my people. "Spouse, keep your wombs well and if the day of birth has come and the newborn is a son, then watch and take care of him. The king replied. "But if the one born is a princess, take her far away the palace. "

Hearing the Kings will, the Empress was stunned. "Why is that, Sire? Is not a princess a hereditary, too? "Said the Empress sad. "Just do what I ask. If I find you do not carry out what I impress, then you are considered a dissident King. And you know the punishment you will get for the king's royalty. "Threatened the King. "Good Lord my lord." The Empress answered resignedly. An unrelenting grief overwhelmed the Queen's feelings of a mother.

So the King set out for his voyage. Months passed by until the baby's birthday came. Through a fast and smooth delivery, was born a daughter to the palace of the Kingdom of Kelumpang. Knowing the child is a baby girl (called the Princess), Empress ceaselessly cried. However, the days were changed, without any intention of the Empress's heart to carry out the King's orders. The beautiful princess is cared for and loved by the entire palace.

It comes at the age of the Princess, who stepped on two months. The Consort also recalled her promise to carry out the King's orders. Queen then asked for advice on Mak Inang that is the oldest ladies among the court ladies. Mak Inang said that the Princess should be taken into the forest and made a house for her protection to the Kelumpang tree. He was sure, because the tree is high would not find the King. However, the Queen remains upset.

Day-after month, months into years, the Princess was growing up. From the age from two months, he was brought by Mak Inang to a shoot from the Kelumpang tree which has built a hut for his shelter. Mak Inang accompanies him every day. The queen only occasionally visited her.

Arriving under the tree, Kelumpang where Princess hid, King called the Princess. "I do not want to go down, but the fabric I made to offer to my lord the king has not finished yet." Princess replied from her shelter cottage. Hearing the Princess's answer, the King was angry. However, nothing he got did. So the king and his guards returned to the palace and so on for two days later. On that day, the Princess finally got off her shelter.

"Princess Pucuk Kelumpang, your father came home from across the place with a scarf and a piece of jewelry and a bracelet. Come down my daughter and your father wants to meet you." Call the Empress gently and sing. Then the voice of the Princess replied with sincerely.

"O my beloved mother, I will come down immediately because the weaving of mine is done. The woven fabric is ready to be offered to my father."

Soon the Princess came down from the Kelumpang tree. She was amazed at the presence of her father whom she had never met. The king did not blink to see the Princess. She saw that her daughter became a beautiful girl, beautifully dyed hair, fair skin and a tall, slender body. But then, the face of the King turned into haunted. Although at first the King was impressed by the beauty of his daughter, but because of the promise, he once conveyed to the Empress first, so he still holds the promise not to accept the Princess. Nevertheless, the princess at the same time beautiful woven works to be presented to the King.

\section{The Value of Character EduCATION IN MALAy TALES}

\section{A. Leadership and Responsibility}

The value of leadership in Malay folklore can be seen through the stories depicted to the life of the King's family. Almost every Malay folklore traced from the Malay Tale is a centrist palace. The centrist-style tale always shows the character of the leader displayed by a King, who is responsible for leading his people, so that his people live justly and 
prosper. Through the story described above, the princess's fairy tale at Pucuk Kelumpang shows the life story of the King, who has extended desired descent, and when the queen is pregnant, as the leader among the people, he strives to continue his role for a leader. This is demonstrated by conducting trade cooperation to various other countries through a long voyage and leaves the Queen, who was carrying a child who is coveted for the prosperity to his people.

The value of leadership is demonstrated through the power structure in the kingdom that is to include: King, Wazir, palace commander, and warrior. In the royal structure of Wazir is a belief of the King, who has always been a place to exchange ideas, and convey all grievances. This is seen in the King's conversation to the Wazir: In his confusion, the King asked for advice on Wazir. Wazir says that if the dream occurs during the day, then the dream will come true.

The value of leadership and responsibility is also shown by the activities of the King, who guard the sovereignty over the kingdom in order to prospering people. In order to fulfill sovereignty and responsibility as a leader, the King departed for months even in years sailing to other countries to cooperate and trade and trade his country's natural wealth for the welfare of his people. The departure of the King is of course very heavy because he left his wife who was pregnant with a child. However, the King did not escape amid the happiness with his wife, so he kept sailing for a long time.

\section{B. Patience}

The value of patients Princess at Pucuk Kelumpang is shown through the role of two figures, King and Princess Pucuk Kelumpang (daughter of the King). The King's patience is shown by the tireless waiting in the hope of a miracle of God for the presence of the offspring of his family. Though the King always thought and reflected and waited for the presence of descendants in the midst of his happy family, but the King remained faithful to the Empress.

The second value of patience is shown through the character of Princess Pucuk Kelumpang, who is unfamiliar in the forest and lives in her residence made to the tree for years from small to adolescence. Her patience has been tested over many years of her own life awaiting her father's return and can accept her as a descendant born as a princess. Her patience was also shown through her devotion to the King by offering a beautiful weave as a gift to be given at the time of the meeting with the King.

\section{Loyalty}

The value of loyalty can be seen from three figures namely the King, Empress, and the Princess Pucuk Kelumpang. The loyalty of the King is shown through his dedication to the State of Kelumpang which, at the time of the Empress's pregnancy, was abandoned for the sake of cooperation with the neighboring countries. While the loyalty of the Empress is shown through her loyalty awaiting the return of the King. Although the Empress was faced with an extraordinary dilemma because of the birth of a Princess, but because of her motherly nature, she remained faithful to the Princess even though she had to violate the King's order to kill her child if the one born was a Princess. The Empress continues to save the Princess by alienating her child to save the child.

In addition to these two figures, there is a character of Princess Pucuk Kelumpang, who teaches the value of loyalty is very meaningful. The allegiance was shown through the weight of the princess in the middle of the forest and exiled in Pucuk Kelumpang Tree. Though the princess knew that she was unwanted by the King, she still showed her devotion and sincerity to dedicate the weaving made from her own hands and produced a very beautiful fabric to offer to her unwilling father.

\section{Honesty}

The moment of the deceitful lie shown by the Empress by burying the goat bone as a substitute for the princess and inviting the crows so that the crows can cover up the lie done by the Empress. This event can be understood before an attempt to protect the child who is born from her womb. As a mother of course, she cannot afford to eliminate the child's life that she has been waiting for. This event shows a mother's honesty value to her child. Honesty in this story is highly esteemed, because of the lies that have been done and in any way to cover it, then the lie will sooner or later be revealed as well. Even the unfolding of the lie had to be reciprocated with profound sorrow with the non-recognition of the princess as the son of the King.

\section{CONCLUSION}

Storytelling is an effective character education strategy for children of early-childhood education in Kindergarten institutions. Internalization of educational values of leadership character and responsibility, patience, loyalty, and honesty must be preceded through the stage of the dissemination or socialization of local stories that contain cultural wisdom. The values of character education shown through characterizations in the story can be absorbed and emulated to manifest in the expression of action in everyday interactions. Educational institutions in this case kindergarten can integrate the process of storytelling activities in learning activities. This activity is also an effort to revitalize local wisdom in schools loaded with character education content. In principle, the development of cultural education and character in children through folklore is very close to the sociocultural aspect and effective in introducing character education appropriate to the age of early-childhood growth.

\section{REFERENCES}

[1] E.B Hourlock, "Perkembangan Anak Jilid I," Jakarta: Erlangga, 1996.

[2] T. Lickona, "Educating of Character," Diterjemahkan oleh Wamaungo, Jakarta: Erlangga, 1991.

[3] S. Endaswara, "Pendidikan Karakter dalam Folklore Konsep, Bentuk, dan Model," Yogyakarta: Pustaka Rumah Suluh, 2013.

[4] W. Sayy, "Panduan Belajar Mendongeng," Yogyakarta: RDI, 2007.

[5] J. Danandjaja, "Folklor Indonesia Ilmu Gosip, Dongeng, dan lain-lain," Jakarta: Grafiti, 2007.

[6] O.Gana, "Batjaan Anak-anak; Pandangan Anak-anak," Jakarta: Balai Pustaka, 1966 
[7] D. Sulistyorini, "Pembelajaran Sastra melalui Media Pembelajaran Visual Cerita Bergambar Cerita Rakyat sebagai Upaya Penanaman Etika Siswa SD di Kabupaten Tulung Agung", unpublished.

[8] N. Rolina, "Media dan Sumber Belajar," UNY: Kementrian Pendidikan Nasional, 2010
[9] P. Rusdi, "Nilai-nilai Budi Pekerti yang Terkandung Dalam Cerita Rakyat Melayu di Sumatera Utara," Banda Aceh: Balai Pelestarian Nilai Budaya, 2013. 